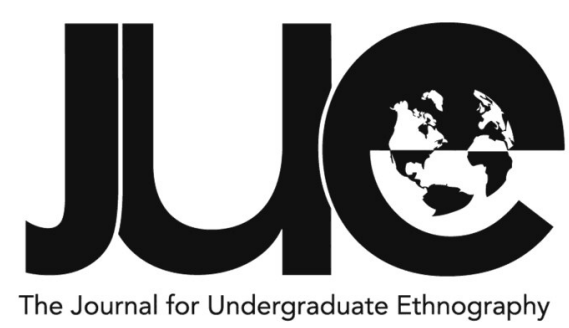

\title{
"We Become Capable of Handling Everything": Gender and Gulf Migration in Kerala, South India
}

Kathryn Gerry

Elon University, kgerry@elon.edu

\section{ABSTRACT}

Women have a uniquely gendered experience with worker migration from Kerala, South India to the Gulf, a phenomenon which touches virtually every household in this state. Drawing on ethnographic fieldwork in Kerala, this article examines the intersections of gender and migration; I argue that migration fuels significant social change in terms of gender expectations and the role of women as economic agents. My fieldwork reveals that women work abroad due to personal circumstances and to conform to local ideas about modernity. Migrants' wives also experience increased autonomy in their daily lives. These two categories of women, migrant women and the wives of male migrants, are attuned to others' perceptions of their roles vis-à-vis migration. Despite occasional negative feedback, women report that they are empowered by worker migration. This project builds on scholarship examining the status of women in Kerala (Eapen and Kodoth 2003), the experiences of migrant spouses (Osella 2016), and female Christian nurses' Gulf migration (Percot 2006). I extend this work by analyzing the personal narratives of individual women who work in the Gulf, head their own households in Kerala, and experience stigmatization because of emigration. Finally, I explored the broader implications of migration for the lifestyles and aspirations of women in Kerala. 
U nder the cloak of pre-dawn hours, I dressed in a newly purchased kurta and walked across the street to join the Hindu priest preparing a housewarming ritual in Kerala, South India. I sat on the lone chaise in the room, still covered in its plastic wrapping, as the priest built a havan (fire altar). As the sun began to rise outside, family members trickled into the ceremony. Today's ritual would cleanse the new house of any negative energy and spirits and prepare it to be inhabited. The intricate rites extended until noon, at which point Seema and Shiv, the new homeowners, welcomed and fed their many guests. In addition to its religious significance, the day was also a celebration and display of the couple's material success. As Seema remarked, "Today we are sharing our happiness, so [our guests] are happy."

Seema returned a few days prior from a year of living and working in Saudi Arabia as a nurse. She wanted to be present for the housewarming of her and her husband's newly constructed home, which was funded in part by her toils in the Gulf. She confided in me that building their own home had been a dream for her and her husband for the past five years. When I asked if the house was what she had pictured, Seema declared, "I finished what I dreamed."

Seema is one of many Malayali (i.e., Malayalam-speaking persons from Kerala) women who migrate for employment and with whom I spent time while conducting fieldwork on the pervasive phenomenon of worker migration from this South Indian state to the Gulf. Relationships with migration are decisively gendered in Kerala, as evidenced by Malayali women's experiences, whether as family members of migrants or those who migrate themselves, in contrast to those of Malayali men. Seema's narrative demonstrates the possibilities for various forms of material, personal, and professional success that migration opens up for women. Furthermore, her narrative prompts questions about how other women in less advantageous situations have navigated this terrain. Malayali women have a unique set of gendered relationships with migration, including a resulting increased autonomy, agency, and independence for them, while men typically migrate to fulfill their gendered duty as a household provider. Drawing on one month of intensive participant observation and fifty-five semi-structured interviews ranging from thirty minutes to three hours which were recorded in Kerala in the summer of 2019, I argue that Seema and other women like her fit into a broader pattern whereby outmigration is catalyzing significant social change in terms of gender roles and expectations. More specifically, I contend that women are empowered through migration both in terms of economic agency, as they earn salaries abroad, and in terms of personal agency as they increasingly head households and assume new responsibilities at home in the absence of their husbands.

\section{Kerala, Migration, and Gender}

This article builds on existing scholarship that examines the status of women in Kerala, the experiences of migrant spouses, and female Christian nurses' Gulf migration. Women's relationships to migration have overwhelming been framed negatively and in terms of their menfolk's absence. Mridul Eapen and Praveena Kodoth (2003), for example, highlight the discrepancy between Malayali women's supposed high social status and their relative lack of economic autonomy and decisionmaking and note that migration-related marital tensions may produce mental health challenges for women. In a study of female Christian nurses, Marie Percot (2006) argues that individualistic aspirations fuel both the desire for a nuclear family model, in contrast to the traditional extended family, and a novel approach to migration where the Gulf is viewed as a stepping-stone for migration to the West. Most recently, Caroline Osella (2016) has critiqued and complicated the somewhat unidimensional picture of Malayali women that 
emerges in the academic literature, where they are characterized as the "Gulf wife." This trope is a gloss for a lonely woman who is rendered helpless by her husband's absence. My own scholarship extends the literature in new directions by analyzing the nuanced narratives of individual women who take on various roles by virtue of migration, whether that means going to work in the Gulf themselves or assuming responsibility for managing their households in Kerala. While many of these women experience success, some experience various forms of gendered stigmatization. Unsurprisingly, these divergent experiences can be linked to key variables, such as class and education differentials, as well as access to resources. My work places these women's narratives in conversation with those of their male counterparts, who frame migration experiences and community reactions to women's roles through their own lenses. In contrast to the existing scholarship, the narratives from Hindu, Muslim, and Christian men and women that I recorded highlight women's self-articulations about the value of their economic and social contributions as well as men's assessments of these activities, and prompt me to analyze recent shifts in the roles and agency of women.

Since the 1990s, the gendered dimensions of Kerala outmigration have not been stable, but rather have shifted as the number of female emigrants has increased and perceptions of women's roles have changed. In 1998, about $10 \%$ of all migrant workers from Kerala to any destination within India or internationally were women (Zachariah, Mathew, and Rajan 2003, 315). By $2004,17 \%$ of Kerala's migrant workers were women (Percot and Rajan 2007, 319). The increase in migration was especially rapid for those migrating to the Gulf. The migration rate for women increased by $143 \%$ between 1999 and 2004, growing from 127,000 to 309,000 , whereas the migration growth rate was only 24\% for men in the same time period (Percot and Rajan 2007, 319). The two most common professions for migrant women included working as housemaids and nurses (Percot and Rajan 2007, 320). Prior to this escalation in women's migration, most scholarship depicted the relationship between migration and women as being characterized by their experience as abandoned wives who were seemingly lonely or incapable. In her research on the impact of male migration on women, Leela Gulati (1993) describes wives facing handicaps as being dependent on their community for support and requiring more education to assume new responsibilities associated with children's education, health care, and finances. Some scholars described the most prominent effect stemming from migration as the separation of wives from their husbands (Zachariah, Mathew, and Rajan 2003, 321). Despite the reality that some women were migrating, the rhetoric remained focused on their status as wives now living apart from their husbands. In a survey conducted in 2003 and focused solely on Gulf wives, scholars characterized women remaining in Kerala and separated from their husbands as highly educated but mostly engaged in household activities (Zachariah, Mathew, and Rajan 2003, 326-27). Furthermore, these women were described as having to overcome the "adverse consequences" of loneliness and added responsibilities (Zachariah, Mathew, and Rajan 2003, 329), effectively casting their experiences in a negative light. While women's experiences might have initially aligned more closely with the "lonely Gulf wife" model, as women's migration became more widespread and socially acceptable, the number and kinds of opportunities shifted and grew; these conditions allowed their experiences to become more complex and edge towards empowerment.

Indeed, my fieldwork participants reported that "in the old days" and "before" women did not migrate often and were mostly housewives. Additionally, many people in Kerala explained that migration used to be advantageous for men to participate in because it elevated their marriage prospects. They argued, however, that migration no longer positively affected marriage prospects, perhaps because of changing dynamics due to the increase in female migration. The characterization of women and migration experiences in the media, such as in movies and songs, has also been focused on sorrowful, lonely wives. For example, Gulf-themed "letter songs," which are revivals of an older generation of songs relating letters between "Ionely, love-lorn" wives and their migrant husbands, became popular at the 
turn of the century (Kurien 2002, 72). Participants explained that these media representations of migration highlighted and dramatized husbands abandoning their wives for the Gulf, while the women who remained in Kerala felt hopeless and longed for their men to return. The lived realities of the women I encountered during my fieldwork contrasts with media depictions of the spouses of emigrants, participants' descriptions of their past experiences of migration, and existing scholarship, suggesting that the phenomenon I witnessed is a part of a recent shift in the gendered expectations and experiences of Gulf migration.

The negative framing of female migration is not specific to Kerala, but surfaces in other academic research on Indian female migrants. Radhika Kanchana (2016), for example, focuses on an exploration of India's paternalistic emigration policy for women, which restricts female migration for the supposed safety of migrants. It is based on the argument that migration leaves women vulnerable to exploitation. This policy privileges protecting women "by citing the practical 'realities'" of exploitation rather than focusing on empowering them, ultimately restricting female's access to the benefits of migration (Kanchana 2016, 100). In other parts of South Asia, pervasive associations between female emigration and exploitation incite similarly restrictive politics. Tom O'Neill (2001, 153) details this phenomenon in Nepal whereby policies that are intended to "rescue" female emigrants ultimately increase instances of trafficking by limiting legitimate migration opportunities. Despite these examples, female migration is not exclusively presented as negative phenomenon throughout academic scholarship. For example, C.Y. Thangarajah (2003) examines Sri Lankan women's experiences of migration to the Middle East and highlights their feelings of empowerment that stem from their migration experiences. The women integrate Islamic religious practices learned during their tenures abroad to "successful(ly) [negotiate] and [recast] their roles" and empower themselves (141). Women's migration to the Gulf, regardless of its framing, is evidently not confined to Kerala. Migration in contexts across India and South Asia are salient because the influence of Gulf migration is as widespread as the migration itself, affecting individuals across the region. Women are thus likely experiencing these shifts in gendered ways, empowering them personally and economically to varying degrees in Kerala, India, and South Asia.

\section{Ethnographic Encounters and Exchanges}

As an American undergraduate researcher, I arrived in Kerala in the summer of 2019 as a relative outsider to the local community where I would base myself during my fieldwork. However, I had assiduously prepared myself by reading relevant scholarly literature, spending four months living and studying in Northern India, and utilizing my mentor's decades-old relationships and ties to Kerala. Building on the foundation of my mentor's networks significantly shaped my project, as it enabled me to identify a translator and meaningfully immerse myself in the communities where I conducted my research project. For the duration of my fieldwork, I lived in the homes of the friends and family of my translator, Sahil, a 24-year-old Hindu man whom my mentor has known since he was a child. I elected to work with Sahil because of his English fluency, familiarity with ethnographic research, and his intimate knowledge of fieldwork locations in his home state of Kerala. I traveled to three regions with Sahil to access a cross-section of religions representative of Kerala's remarkable diversity. The state is significantly more religiously diverse than the rest of India. According to India's 2011 census, Kerala's population is 55\% Hindu, 27\% Muslim, and 18\% Christian, reflecting numbers for minority religions that are well above the national averages (Government of India Ministry of Home Affairs 2011a). The corresponding national averages are $80 \%$ Hindu, 14\% Muslim, 2\% Christian, and $4 \%$ other religions according to the 2011 census. Elsewhere I have explored themes grounded in this religious diversity, examined the multireligious landscapes of Kerala and the Gulf, and analyzed the relationship between the two in order to argue that shifts in the multireligious landscape in Kerala are ambivalent in nature (Gerry 2021). 
In these communities, Sahil and I conducted open-ended interviews with the friends and family of Gulf migrants and engaged in field visits to religious and social spaces. The migrants themselves worked in a range of professions including as drivers, construction workers, housemaids, nurses, sales professionals, tailors, and business owners. All of my research participants were adults, with the youngest being an 18-year-old child of a migrant and the oldest a 64-year-old ex-migrant worker. Sahil and I recorded each interview and then spent our evenings transcribing and translating them. Pseudonyms were assigned to anonymize my interlocutors.

Working closely with Sahil provided a window into one set of Malayali perspectives, as he helped me bridge my outsider standpoint with his and others' insider points of view. Collaborating with him and translating interviews within the context of a homestay situation added several additional interpretative lenses to this project, as family members, visitors, and others would often interject their own understandings of the relationships between religious communities, India's political climate, and the experiences of religious minorities in Kerala as we worked. This parallel body of commentary contextualized my interviews by revealing unrehearsed reactions and inter-community understandings and perceptions. To augment the narratives we were recording, Sahil and I ventured into the surrounding communities to observe architecture and styles of dress in order to develop a fuller understanding of the Gulf influence. As detailed below, combining this community observation with participants' narratives revealed tangible markers of social change and the influence of migration in women's dress. We also analyzed social media during our free time and used this analysis to raise new questions in our interviews about innovative forms and usages of social media to understand the ways in which Gulf ideas penetrate local communities virtually. These processes allowed me to identify and appreciate the ubiquitous influence of the Gulf in the everyday lives of Malayalis. In addition to the everyday effects of Gulf migration-initially almost invisible but truly pervasive once I learned how to refocus my gaze and isolate them-special events like Seema's housewarming offered a unique opportunity to observe a significant life cycle ritual made possible, in part, by Gulf money. Throughout my fieldwork I developed my ethnographic sensibilities to become attuned to the dynamics of everyday situations and to learn from the micro-moments that are crucial to ethnographic research.

As Heike Moser and Paul Younger $(2013,137)$ note, Kerala's distinct social makeup is a key factor making it suitable for ethnographic research surveying religious landscape. Moreover, since Gulf worker migration touches virtually every household in the state, Kerala was an exceedingly rich location for my fieldwork. The 2018 Kerala Migration Survey, for example, found that $67 \%$ of households had at least one member living in a Gulf state (Rajan 2018). Migration from Kerala took hold in the 1950s amid the growing demand for manual labor in Gulf construction, surged in the 1970s and 1980s with the growth of the oil industry, and later extended into professional fields, including medicine, sales, and technology (Gardner 2011; Miller 1992). In addition to being studied because of its unique migration patterns, Kerala has drawn attention because of its "model state" identity: it has the nation's highest literacy rate as well as the lowest rates for infant mortality, maternal mortality, and fertility (Government of India Ministry of Home Affairs 2011b; Government of India Ministry of Home Affairs 2013). However, Kerala's high social development indicators rest on a weak economic base, with the state's unemployment rate registering at double the national average (Eapen and Kodoth 2003; The Lede 2019). Moreover, this positive characterization of a "model state" notwithstanding, I continued to have questions about the quality of life for women in Kerala, particularly in terms of social roles and relations. Given this backdrop, my fieldwork sought to answer questions concerning the extent to which women experience and self-report empowerment and agency and to what degree they might experience certain types of gendered stigmatization because of their relationships with migration. Here I use the term "empowered" to signal women's own expressions of increased agency, confidence, 
and capability as they take on new roles vis-à-vis migration. While I recognize that this term is context-sensitive and culturally located, I employ it to highlight that I take seriously women's self-perceptions and thus utilize this term located within their self-articulations.

\section{Narratives of Social Change}

The narratives of individual women who work in the Gulf illustrate social changes occurring around gender roles and expectations, partially because many Malayali women take jobs in the Gulf in alignment with locally constructed ideas about modernity. Seema, for example, explained to me that "before [her lifetime] girls were not supposed to be sent to far places for studying." However, because of "modern" ways of thinking-such as allowing girls to obtain high levels of education and travel or live alone for their education or work-prevalent in Kerala today, Seema noted that girls "can make choices [and] have the right to decide what [they] want." Seema is not a third-party observer of the local situation vis-à-vis gender expectations; rather, in sharing these observations, Seema was effectively telling her own story. She was educated in Kerala and attended school and worked away from home in India before moving to Saudi Arabia to work as a nurse. As such, she is an exemplar of modern values of women's education and independence.

Seema's story illustrates the increased autonomy drawn from worker migration because of her position as an economic agent. Her narrative contrasts sharply with the prevailing portrait of Malayali women in earlier scholarship, which depicts them as subordinate to men due to their relative lack of financial decision-making abilities (Eapen and Kodoth 2003). Seema's profession as a nurse, which requires specialized education, as well as her control of financial resources, signal her social status in Kerala. She breaks the mold of the socalled "Gulf wife," who is cast as suffering from loneliness and mental distress in the absence of her migrant husband. Instead, as a female migrant who embraces her experience, Seema offers a counterpoint to the Gulf wife stereotype and therefore confirms Caroline and Filippo Osella's (2008) challenges to that trope.
Her narrative thus points to a new reality in which direct migration is one clear pathway for women to attain economic mobility and raise their social status.

Seema's migration decisions were not inspired by the individualistic desires that are often linked to "modern" worldviews. Rather, she dedicated herself to her education, possible only through the financial contributions and support from her extended family, so that she could improve her family's economic status. This pooling of support is part of a broader pattern in contemporary India whereby families merge their resources to amass enough capital to advance the education and career prospects of a specific individual with the understanding that this family member will reciprocate by assisting other family members with future support and benefits (see, for example, Dickey 2002). The collectivist effort of her network ultimately allowed Seema to attain social mobility and success that she hopes to share with her family. According to Seema:

I wasn't born into a high, rich family...So we are low class; they consider [us] like that...। want to make my mommy happy and I want to make her relax...Only for that I wanted to make some money. I want to make my mommy comfortable. She struggled, a lot-I can't say, I don't have words....So for my family and to safeguard my future generation, I don't want my child to struggle like me. And I mainly want to give rest to my mother.

Seema related her story to me while we sat in her new home with her family. They appeared to be financially secure now; her sister is married to a chef who is working in the Gulf and has two happy, healthy children. Seema achieved her initial aim of "settling" her family into a comfortable lifestyle. Their newly constructed house, housewarming ritual, and food choices were all clear indicators of the middle-class status Seema had attained. Now she was looking beyond India and nurturing global ambitions to migrate to Ireland, following the pattern of many Gulf migrants who turn to Europe as a further goal. Seema never planned to remain in the Gulf because she did not find the lifestyle of migration, being separated from her husband, and the culture of Saudi Arabia to 
suit her long-term. Instead, she dreamed of migrating to Europe with her husband, as a couple rather than solo, and enjoying the higher salary and Western cultural opportunities available there. Migration to the Gulf for Seema was a crucial step in her journey towards achieving her goals by providing her the opportunity to have substantial economic agency and career development which she could build on with future migration.

Seema's desire for global migration aligns with Percot's (2006) observation that nurses utilize the Gulf as a stepping stone to acquire financial means and experiences that position them well for Western migration. Percot, however, argues that the catalyst for these global ambitions is a shift towards individualistic aspirations in Kerala (48). By contrast, Seema's dreams do not appear to stem from a desire for individual success but are instead more collectivist in nature. Her narrative demonstrates that Seema's priorities are more family-focused than self-focused. Specifically, Seema has concentrated her energy on her mother, evident in her desire to make her mother feel comfortable and settled. Seema's deep love, admiration, and gratitude for her mother became evident in our interview, as well as her desire to repay her mother for struggling to raise and educate her. Seema even expressed a desire to bring her mother with her to Ireland if given the opportunity, so that they could share in her success together. These dreams resonate with the traditional understanding of selfhood propagated by scholars of South Asian society, who identify the widespread existence of collectivist societies. The concept of the "dividual," in contrast to the individual, signals the collective nature of thinking in terms of a community or family (Marriott 1989; Strathern 1988). Karl Smith (2012) extends the selfhood discussion by delineating the "porous" versus "buffered" self, pointing to those who are inherently socially embedded versus those who are guided by self-centered motivations. The notions of joint responsibilities and shared triumphs, as exemplified by Seema's family merging resources to support her academic and professional endeavors, signal the socially embedded and "porous" self that Marriott and Smith identify as prevalent in South Asia. The trend that Percot (2006) identifies of Christian nurses who dream of migrating to the Gulf first and then on to the West in order to escape familial responsibilities and enjoy their own personal successes aligns with the self-centered motivations of the "buffered" self that is advanced in Smith's analysis. Seema, I argue, represents a hybrid and modern collectivism by possessing a globalized worldview with aspirations beyond India while prioritizing her family and maintaining a socially embedded "porosity" in her relationships. Collectivism, which produced the conditions for Seema's own success, molds her worldview by motivating her to prioritize the needs and goals of her family members. However, her collectivism is clearly influenced by her global ambitions which ultimately drive her to move away from some or all of her extended family members when migrating. Seema's experience thus combines these identities and bridges the gap between a cosmopolitan individual and collective society by being a globally ambitious woman embedded within a collectivist society who maintains commitments to her family.

While Seema's story is characterized by success and ambitions realized, there are less rosy aspects to many women's migration stories. These women's personal circumstances may drive them to work in the Gulf for entirely different reasons than Seema, especially due to economic necessity arising out of poverty. For example, I interviewed a woman in her midfifties named Sabirah who worked as a housemaid first in Saudi Arabia and then in the United Arab Emirates. Her migration began over a decade ago after she was forced into the breadwinner position when a decline in her husband's health rendered him unable to work. With her earnings, she was able to arrange the marriages of her daughters and sustain her family at a minimal economic level. Sabirah described how she experienced mental distress, including suicidal thoughts, due to her migration and the subsequent disintegration of family relationships. Despite her precarious situation, however, Sabirah persevered in supporting herself and her family, demonstrating the economic agency attained even in the darkest situations of Gulf migration. Although the two women share in having gained economic agency from their migration 
experiences, Sabirah's narrative represents a migration experience distinct from Seema's both because her migration motivation arose from necessity rather than ambition and her financial success was tainted by her declining mental health and family relationships.

Despite Sabirah and Seema's narratives, nearly all of the women I interviewed were wives, shaping the focus of my analysis. It appeared uncommon for Malayali women to travel to the Gulf before marriage. Most families are unwilling to allow their unmarried daughter to travel far without supervision; the pressure to safeguard a young woman's "purity" and reputation in order to protect her marriage prospects persists in India. This pervasive concern over women's honor and propriety manifests in a resistance to single women's migration. Thus, although wives gain agency via their relationships with Gulf migration, their participation hinges upon their husband's choice to leave them behind in Kerala or his approval for them to migrate themselves.

\section{Confidence, Economic Agency, and Independence for Migrant Wives}

My fieldwork demonstrates that when males migrate to the Gulf, a range of new opportunities for increased independence and autonomy are available to their wives as these women manage their households and engage in work beyond the domestic sphere. Viyasha, the 23-year-old daughter of a migrant worker, described to me the influences of migration on her family, emphasizing the experience of her mother. Her father began migrating to Dubai for manual labor nearly two decades ago, when Viyasha was just a few months old. Despite her father's extensive tenure in the Gulf, when asked to discuss migration Viyasha focused on her mother and explained: "After [my father] went to the Gulf, my mother took care of everything here." All of the roles that her father had previously held, which are traditional for men to assume, Viyasha's mother adopted overnight. These roles included arranging and directing her children's education, managing the building of a new home for her family, and handling the financial decision-making for their newly acquired Gulf money. Viyasha's mother did not ease into these new roles effortlessly; rather, according to Viyasha, "she faced a lot of difficulties, but she thought it was her duty, so she suffered." The new roles and responsibilities that arose from her husband's migration transformed Viyasha's mother. She was not always the confident and capable woman that her daughter described: Viyasha explained that "when she was married she was a shy woman," but ultimately "she knows more than my father now" and "takes care of us the most." Viyasha's words paint the picture of a woman emboldened by the increased autonomy migrant wives experience, and her tone of pride in her mother evident throughout the interview indicated her own inspiration and the potential for multi-generational influence.

In a study of a female Hindu ritual healer from South India, Amy L. Allocco (2013) explores the ways that individual women may provide new models for other women and cause them to reimagine what is possible for their own lives. She argues that Valliyammal, the healer, "may enlarge the realm of gender possibilities and open up alternative gender ideologies for...many women (and men)" (107). She argues further that by providing what Jayati Lal calls "counternarratives," or life experiences that counter the traditional gender roles and expectations for women, Valliyammal effectively provides a new model of the female experience to "enlarge the social imaginary" (106). In this way, women like Valliyammal, Seema, and others I interviewed offer new life-scripts for the roles of women in Kerala through the examples of their own experiences and "counternarratives." This influence was evident in Viyasha's aspirations as she was studying for a Master of Commerce degree and making plans for a professional career. Viyasha, like her mother, desired the responsibilities that accompanied independence.

Viyasha and her mother exemplify the bond produced by shared intergenerational relationships with migration. Such relationships formed vis-à-vis family members' migration are common in Kerala. As the mother of three children whose lives have all been touched by migration, Seema's mother, Mala, is a prime example. Her eldest daughter, Seema, and her 
son, Shardool, have both migrated to the Gulf for work and her youngest daughter, Saakshi, is married to a chef who works in the United Arab Emirates. Saakshi has a daughter and son both under the age of three and is herself only twenty-four. Thus, while Saakshi's husband is working abroad, Mala has stepped in and moved into her daughter's house in northern Kerala to help with managing the children and household duties. Mala, of course, has her own home, spouse, and domestic responsibilities, but she chose to make a sacrifice by staying at Saakshi's home to assist her daughter. Her choice fits into the aforementioned pattern of a collectivist society, as Mala privileged her daughter's needs, happiness, and success above her own. Mala admitted that while she felt the negative effect of leaving her own life behind by moving to Saakshi's village and being away from her home and husband, she explained that she willingly made this sacrifice for her children. Saakshi's narrative and discourses around Gulf migration demonstrate that individuals, both men and women, are prepared to temporarily forfeit their own desires and make what they regard as shortterm sacrifices to help members of their family achieve economic stability and experience success. This sacrifice did not go unnoticed by Saakshi, who explained that she needed her mother's assistance because the increased responsibilities, especially managing children, were difficult for her to handle. Mala demonstrated confidence in the abilities of women to overcome challenges associated with migration, whether it be individuals putting their family members' needs above their own or adopting new roles. Speaking generally, but drawing on her experiences with her family, she related: "We will overcome the problems. When they aren't here, [our men], we take their responsibilities. We are able to do that. When they aren't here, we do everything. So, we get the courage to do it." Without hesitation, Mala reported that she and Saakshi were able to jointly manage the household without any problems and observed her daughter gaining independence through the process.

In addition to woman-headed households, migrants' wives also gain economic agency by venturing outside of the domestic sphere to enter the workforce in Kerala. Numerous twenty-something wives I interviewed had jobs with a range of time commitments outside of their homes. One example is Prerana, a 29-year -old Hindu, who works as a technician in a medical laboratory. She also engages in other activities outside of the home to enrich her days. She shared, "After my job I will go to music class and stitching class. I feel like music is a way of meditation." Prerana filled her day with work and activities to stay "busy" in her husband's absence. In an article from the early 2000s, the Osellas $(2006,583)$ described an opposite trend of "re-gendering ... Kerala's modernity" and projected standards of modernity on women by bringing them into the household whereby families in Kerala desired for their women to transition from manual workers to housewives as a marker of becoming more modern. Families yearned for their women to be housewives to display status within their communities, because women remaining within the domestic private sphere demonstrated economic stability. The gendered valorization of women becoming housewives was derived from the bourgeois ideal of the "lady of the inside" (Osella and Osella 2000b, 42). This ideal resonated as an ambition with Malayali families because it starkly contrasts with many of their realities at the time, which demanded women to engage in manual labor, such as farming, to aid in supporting the family. Beyond gendered expectations, there is also a "gendered distinction between different kinds of spaces" in Kerala, such as those divided along the lines of private and public spheres (Thiranagama 2019, 325). These distinctions emerge clearly around sociality, as it is socially acceptable for men to gather in nearly any public space while women are confined to a "private-public" space existing within the bounds of their homes and neighborhood (Thiranagama 2019, 325-26). According to these traditional gender distinctions, migrant wives would not typically be expected or encouraged to leave their private sphere (Osella and Osella 2000a). Prerana's experience contrasts with both of these distinctions in that she engaged in the public sphere for both her work and her hobbies.

Through technology, Prerana has been able to stay connected with her husband in the six years that have passed since he began 
migrating. Although she reported being lonely in her husband's absence, she also defied the stereotype of the abandoned Gulf wife by finding personal efficacy within her changed circumstances in his absence. According to Prerana:

We feel sad now, but we become capable. [Other] wives don't go out and they are lazy. Like when going to the bank, they think they don't know how and can't do it ... That is how it is for wives with husbands who do everything. Sometimes we miss [our husbands]. Sometimes we go with [other wives] and they say, "I don't know how to do that." It is all done by their husbands. So we feel jealousy towards them. We think about how our husbands are not here. But we become capable of handling everything.

Prerana does not head her own household and lives with her mother-in-law, but she evidently is changed by her roles vis-à-vis migration because she wields increased agency and autonomy. Although she sometimes misses her husband or is envious of women with husbands living at home, these feelings do not inhibit her ability to learn how to successfully manage new responsibilities and perform previously unfamiliar roles. Women sometimes draw on the support of or reside with their extended families so as to not compromise their respectability. However, they can assume increased decision-making ability in the absence of their husbands and through activities such as overseeing or supervising agriculture work and handling marriage arrangements and other life-cycle rites. Migrants' wives who remain in Kerala thus experience agency by leading their households and their lives, often with the support of their female family members, while their husbands migrate.

Nearly all of the women I interviewed were wives, shaping the focus of my analysis. It was uncommon for Malayali women to travel to the Gulf before marriage. Most families are unwilling to allow their unmarried daughter to travel far without supervision; the pressure to safeguard a young woman's "purity" and reputation in order to protect her marriage prospects persists in India. This pervasive concern over women's honor and propriety manifests in a resistance to single women's migration. Thus, although wives gain agency via their relationships with Gulf migration, their participation hinges upon their husband's choice to leave them behind in Kerala or his approval for them to migrate themselves.

\section{Community Response}

In close-knit communities within Kerala in the age of globalization, aspiration, and competition, individuals are often hyper-aware of others' evaluations of their own and their family's conduct, especially given the collectivist tendencies of Indian society. Malayali women are particularly attuned to others' perceptions of their roles vis-à-vis migration, which may range from respect and admiration to jealousy and disdain. Sabirah faced stigma throughout her career as a migrant; her sons did not appreciate the sacrifices she made for their family and instead rejected their mother for abandoning them. In an emotional moment, Sabirah detailed her eventual split with her sons, stating, "I went abroad because of our problems... because I needed to take care of them and their marriages...[but] they are not willing to [understand] that... They keep blaming me." Furthermore, she explained that people within her community often react negatively to female Gulf migrants, questioning them and any success they achieve more regularly than people would scrutinize their male counterparts. The stigma surrounding women's migration is rooted in an affinity for and valorization of traditional family structures, evident in the persisting belief that a household cannot function when the woman is abroad as well as the tendency to pass judgment on female migrants for neglecting their familial duties.

Some women, however, claimed that negative migration stereotypes are outmoded and a thing of the past. Seema's experience directly contrasts with Sabirah's: Seema argued that although people were previously unwelcoming to the idea of women migrating for work, today people are more educated and understand that men and women desire comparable job experiences. Thus, she believes people's attitudes have changed to accept migrant women workers. Seema and Sabirah's 
divergent experiences point to their disparate economic and social statuses as well as the different attitudes that prevailed during the periods when they were migrating. Seema being accepted as a worker within her community and her worldview reveals her own education and economic stability. Although her husband is employed in a coveted position in Kerala as a government worker, it was only because of her second income that her family was able to engage in additional discretionary spending such as constructing their new home. Seema's migration was thus not the result of destitution but rather was catalyzed by economic and globally facing ambition. Sabirah, on the other hand, was the main breadwinner for her family and engaged in unskilled labor out of sheer necessity. She also began working during a time when fewer women were migrating and were doing so for lower-waged and lower-status jobs. My fieldwork confirms Sharika Thiranagama's (2019, 314-315) insight that people remain contained to their social circles by enacting their lives in their localities, or their "private-publics." Although Sabirah's migration began in a time period with different standards for women's work and independence, the stigmatization she faced persists into her reality today. Within her community, Sabirah was anomalous and surrounded by people who did not share the more educated and accepting worldview which Seema encountered. The narratives of Sabirah and Seema highlight the differential of experience by class and education. I contend women existing in both of these socio-economic spheres gain empowerment-whether autonomy and increased economic independence in the case of Sabirah or personal and professional success for Seema-commensurate with their social circles, education, and class contexts.

As the spouse remaining in Kerala, Seema's husband Shiv was conscious of negative community opinions surrounding his wife's migration but he was unconcerned by them. Shiv explained that he was aware of some people who would gossip about his family situation because his wife was the one migrating rather than him. Indeed, their situation, where the woman was engaged in migration while her husband remained in
Kerala, is somewhat unique: of my fifty-five interviews, I only have four examples of this gendered pattern. Although the number of women migrating I encountered was low, I expect that Seema and those like her are on the leading edge of a growing trend as many young wives expressed willingness to migrate to the Gulf if they could obtain a suitable job. Shiv noted that any community whispers about Seema likely centered around her working abroad so that their family could earn more money in addition to Shiv's government job salary. Others in the community may gossip about a migrating wife, but simultaneously respect her efforts and her hard work. Community chatter can thus both be understood as jealous and admiring. Moreover, the opinions of outsiders were not important to Shiv because, according to him, "we know each other, and other families know [us]...I'm not concerned by others." While Shiv was not personally worried and instead was proud of his wife and her work, his ability to disregard comments is not perhaps unsurprising because as a man he has the privilege to be less concerned with others' perceptions. It is also plausible that their family faced less stigmatization since Shiv held his own respected government position, signaling their socio-economic status and reflecting Seema's ability to migrate based on her ambitions. The negative evaluations may then prevail not for Seema and Shiv, but within communities who undertake migration out of economic precarity and necessity.

Seema's mother, Mala, concurred that Seema's experience was not that of a typical Malayali wife. She explained that "in Kerala, after marriage a woman will stay in her home... it is different for Seema." However, she denied that people gossiped about Seema. Despite leading a different life, Mala was proud of her daughter's work and believed others in the community shared this admiration and respect. Mala herself seemed to espouse relatively progressive ideals about her daughter's migration, noting that Seema worked in Saudi Arabia for her family's stability and control over her life. It was apparent Mala recognized Seema's migration as being a means to reach her ultimate life goals and thus worthy of 
drawing any potential censure from her community.

Mala may have been predisposed to support her daughter's pursuits because of their caste background. Their family belongs to the Izhava community, a caste known for its upward social mobility between the nineteenth and twentieth centuries (Moser and Younger 2013, 145). According to the Osellas, in the nineteenth century the caste was made up of "a small landowning and titled elite and a large mass of landless and small tenants who were largely illiterate, considered untouchable, and who eked out a living by manual labor and petty trade" (Osella and Osella 2000b, 8). By the twentieth century, the Izhavas had "expanded their horizons beyond the confines of state and nation" through the pursuit of "social mobility in many social arenas" (Osella and Osella 2000b, 8). The influence of their history of social mobility on the Izhava community today is significant and was clearly evident during my fieldwork. Shathvika, the mother of my translator, sat in a meditative prayer every Friday evening for one hour for the wellbeing of her Izhava neighbors and community. This prayer was inspired by Narayana Guru, a "saintly figure" amongst Izhavas who fought for the dissolution of caste barriers (Moser and Younger 2013, 146). Beyond this weekly prayer at home, I also travelled with my translator to a Narayana Guru temple on multiple occasions to participate in a community prayer and meal. A sense of Izhava identity is threaded through the daily lives of my translator and his family. Moser and Younger (2013, 150-151) contend that Gulf migration allowed for the continuation of the "quest for social mobility that had characterized [Izhavas'] identity since the time of the Narayana Guru." Mala's description of Seema's global pursuits aligned with this understanding of migration for mobility; as she claimed, "[Seema] will be able to do everything by migrating to the Gulf. When we are in India we cannot move forward." Seema's financial and professional advancement is part of a set of objectives that her mother recognizes and supports. It is thus not only young migrants who look beyond India, but also older generations and family members who acknowledge the opportunities that lie abroad in the Gulf.
Although people in Seema's circles spoke positively about her migrating role and discussed her story openly with pride, it can be a more sensitive subject of discussion for other women. I was fortunate enough to speak with numerous women about their experiences vis-à -vis migration. However, nearly all of the interviews with women I conducted were not in private settings. There was always a husband standing behind, a mother-in-law on the couch, or a father in the corner. Even in the rare situations where I found myself otherwise alone with a woman, my male translator was invariably present. Consequently, I venture that these women's voices may have been filtered by their immediate audiences. The interview with Viyasha was one of the unusual instances in which her husband's family gave us privacy and allowed myself, Viyasha, her sister-in-law, and my translator to conduct our interviews alone on the upstairs balcony. As described above, Viyasha proudly shared details about her mother's life as the wife of a migrant. I postulate that Viyasha shared her feelings about her mother's and father's roles in their household openly because of the absence of a family audience. After speaking with Viyasha, I inquired about also interviewing her mother, but this request was initially brushed off and ultimately rejected. Although it is impossible to confirm this, I conjecture that her hesitation resulted from a fear of stigmatization or discomfort with sensitive topics, which may reflect her age and time period of migration. While respondents were not often very explicit about the backlash felt in their communities, I could sense its lurking presence in these moments of hesitation and censoring from women.

\section{Conclusion: The Implications of Migration and Influence}

The looming influence of Gulf migration, similarly, could be felt throughout Kerala. It stretched beyond the immediate households of Gulf migrants into the lives of their extended families, the markets and shops in towns and villages, and the imaginations of every Malayali. The nature of my fieldwork-spending night and day living with families in Kerala-shed light on this reality, especially for the family of Sahil. I developed a close bond with Shathvika, 
Sahil's mother, despite our language barrier. Every evening she would return home from a long day of work at a local factory and immediately begin housework. However, amidst her cleaning she would find the time to pause in my room, insist on bringing me chai or snacks, inquire about my day, and tease me with the few Malayali phrases I knew. Shathvika held $a$ job at a clothing factory during the weekdays, tended crops on the family plot on the weekends, and performed the household duties of cooking, cleaning, and looking after elderly relatives. Her tireless work signaled to me her dedication to her family and the hopes and dreams she held for them. Shathvika did not engage in this work to pass time, stay busy, or further professional ambitions. Unlike Prerana, she did not leave the house for leisure activities or look for new opportunities to stay busy. Rather, like Sabirah, she labored out of sheer necessity. However, Shathvika's experience is distinct from Sabirah's because although they both act as economic agents, Sabirah also operates as a financial decisionmaker as the sole breadwinner for her family while Shathvika's husband remains the designated head-of-household. As a result, the autonomy or increased economic independence often associated with migration thus evaded Shathvika. Evidently, labor for women both as Gulf migrants or in Kerala engenders varying degrees of autonomy and empowerment.

Shathvika's ambitions emerge from a history of Gulf migration in her family and community. Three of her brothers, all of whom I interviewed, and countless other relatives are Gulf migrants. The house in which I stayed was newly constructed, with generous donations from one of her migrating brothers. Sahil remarked to me while we worked one day that the laptop sitting on the desk between us was itself a tangible marker of Gulf money. Their family was directly touched by migration, although they were not migrants themselves. This close proximity to the Gulf, via migrants, fuels a culture of aspiration that drives shifting lifestyles and ambitions. Shathvika comes from a meager background and works industriously to support her family, but she dreams of success for her sons. She prays daily her sons will find employment and explained that once they had stable jobs and wives, they would build a second story to their house so they could each have their own rooms after marriage. For Shathvika, her community's response to migration is evident in her aspirations for her future and her children, and her assiduous work to attain them.

Travelling through towns and villages, I witnessed the influence of the Gulf in the ways people dressed and through the windows of shops. Respondents reported a marked increase in the number of Muslim women donning purdah or hijab (various forms of covering and headscarves, respectively), and Sahil claimed they now appeared frequently in stores where they were not seen five or ten years prior. Research participants explained the growing popularity of Gulf-inspired styles as indicators of social and religious trends, including increasingly "modern" styles of dress or increased religiosity. Donning purdah or hijab can thus be a result of Gulf influence and the head coverings can be considered as cosmopolitan clothing styles. Exclusively Muslim women participate in adopting Gulf clothes styles, but the fashion choice both instigates and is indicative of increased personal religiosity and increasing distance between religious communities. While there are differentials of experiences vis-à-vis Gulf migration by religion (see Gerry 2021), I contend that the empowerment of Malayali women catalyzed by this migration cuts across religious distinctions. Women, whether they migrate themselves or are influenced by friends and family who migrate, thus embody globalized worldviews through the micropractices of cosmopolitanism evidenced by tangible changes in their dress. Gulf clothing styles and Shathvika's aspirations indicate the strong connections felt by Malayalis across Kerala to other parts of the world. Moser and Younger (2013, 151) highlight the feelings associated with these ties where they observe, "Malayalis today seem prouder than ever of their exposure to the outside world." The perceived and physical global connections cultivated by Gulf migration affects women's life choices, ranging from clothing to professional career to lifestyle and household management, illustrating the pervasive nature of the Gulf influence. The ubiquity and pervasiveness of 
the effects of Gulf influence are, I argue, particular to Kerala, where the shifts in gendered expectations and migration experiences are observable among migrants and their families more broadly. The sheer number of Malayali families who are directly touched by Gulf migration means that the Gulf meaningfully influences people throughout the state, seeping into communities, homes, and consciousness at every level.

Malayali women, ranging from migrants themselves to the families of migrants to community members, are becoming empowered through shifts in gender roles and expectations catalyzed by Gulf migration. Women in Kerala are influenced by the expanded range of possibilities the experiences and "counternarratives" of migrant wives and migrating women provide. Consequently, their aspirations and gender expectations are shifting to encompass this widened range of possibilities. Moreover, the personal agency, whether it be through expanded agency, increased autonomy, or growing confidence, of migrant wives increases as they lead households and acquire new roles and responsibilities in Kerala. For female migrants, despite sometimes negative evaluations or backlash, which seem to be indexed to class, women report that they are empowered on the everyday level by worker migration. The women who experience material, personal, and professional success as well as those who are faced with less advantageous circumstances all can garner increased autonomy, agency, and independence by way of their relationship with migration. Indeed, Seema explained that she herself is empowered as a woman in Kerala and felt that she, in her own words, "can make my dreams come true," whether those are to build her house, support her family, or move around the world on to a European destination. 


\section{Acknowledgements}

My fieldwork was generously supported by the Multifaith Scholars program, a grant from Center for Research on Global Engagement, a Center for the Study of Religion, Culture and Society Summer Research Fellowship, and a Rawls Endowed grant at Elon University. I am grateful to this institution and these funding resources as well as for my mentor, Dr. Amy L. Allocco, who provided feedback, guidance, and support throughout the research process. I am also grateful to the anonymous reviewer for JUE whose feedback improved the strength of my arguments and the quality of my submission. 


\section{References}

Allocco, Amy L. 2013. “From Survival to Respect: The Narrative Performances and Ritual Authority of a Female Hindu Healer." Journal of Feminist Studies in Religion 29 (1): 101-117.

Dickey, Sara. 2002. "Anjali's Prospects: Class Mobility in Urban India." In Everyday Life in South Asia, edited by Diane P. Mines and Sarah Lamb, 214-228. Bloomington: Indiana University Press.

Eapen, Mridul, and Praveena Kodoth. 2003. "Family Structure, Women's Education and Work: Re-Examining the High Status of Women in Kerala." In Tracking Gender Equity Under Economic Reforms: Continuity and Change in South Asia, edited by Ratna M. Sudarshan and Swapna Mukhopadhyay, 227-268. India: International Development Research Centre.

Gardner, Andrew M. 2011. "Gulf Migration and the Family." Journal of Arabian Studies 1 (1): 3-25.

Gerry, Kathryn. 2021. "There Is Not a Thing Like Religion or Caste between Migrants': Navigating Multireligious Landscapes in Kerala and the Gulf." Journal of Theta Alpha Kappa 45 (2): 1-16

Gulati, Leela. 1993. In the Absence of Their Men: The Impact of Male Migration on Women. Thousand Oaks, CA: Sage Publications.

Kanchana, Radhika. 2016. "Are India's Policies Increasing the Vulnerability of Its Female Migrants in the Arab-Gulf Countries?" In India Migration Report 2016: Gulf Migration, edited by S. Irudaya Rajan, 90-105. New Delhi: Routledge.

Kurien, Prema A. 2002. Kaleidoscopic Ethnicity: International Migration and the Reconstruction of Community Identities in India. New Brunswick, N.J: Rutgers University Press.

Marriott, McKim. 1989. "Constructing an Indian Ethnosociology." Contributions to Indian Sociology 23 (1): 1-39.

Miller, Roland E. 1992. Mappila Muslims of Kerala: A Study in Islamic Trends. 2nd ed. Madras: Orient Longman.

Ministry of Home Affairs, Government of India. 2013. "Compendium of India's Fertility and Mortality Indicators 1971 - 2013," table T-1 India and Kerala, accessed July 15, 2021. https:// censusindia.gov.in/vital_statistics/Compendium/Srs_data.html. 
_-_. 2011a. "Kerala Religion Census 2011," Census 2011, table 1, accessed July 15, 2021. https://www.census2011.co.in/data/ religion/state/32-kerala.html.

2011b. "Literacy in India," 2010 to 2011, Census 2011 table 1, accessed July 15, 2021. https://www.census2011.co.in/ literacy.php.

Moser, Heike, and Paul Younger. 2013. "Kerala Plurality and Consensus." In The Modern Anthropology of India: Ethnography, Themes and Theory, edited by Peter Berger and Frank Heidemann, 136-156. London; New York: Routledge.

O'Neill, Tom. 2001. "'Selling Girls in Kuwait': Domestic Labour Migration and Trafficking Discourse in Nepal." Anthropologica 43 (2): 153-164.

Osella, Caroline, and Filippo Osella. 2000a. "Migration, Money and Masculinity in Kerala." The Journal of the Royal Anthropological Institute 6 (1): 117-133.

-_- 2000b. Social Mobility in Kerala: Modernity and Identity in Conflict. London, United Kingdom: Pluto Press.

-_- 2006. "Once upon a Time in the West? Stories of Migration and Modernity from Kerala, South India." Journal of the Royal Anthropological Institute 12 (3): 569-588.

- - . 2008. "Nuancing the Migrant Experience: Perspectives from Kerala, South India." In Transnational South Asians: The Making of a Neo-Diaspora, edited by Susan Koshy and R. Radhakrishnan, 146-178. New York: Oxford University Press.

Percot, Marie. 2006. "Indian Nurses in the Gulf: Two Generations of Female Migration." South Asia Research 26 (1): 41-62.

Percot, Marie, and S. Irudaya Rajan. 2007. "Female Emigration from India: Case Study of Nurses." Economic and Political Weekly 42 (4): 318-325.

Rajan, Dr. S. Irudaya. 2018. "Kerala Migration Survey." Thiruvananthapuram: Centre for Development Studies. http:// cds.edu/research/ru/migrationresearch/migration-survey-data/.

Smith, Karl. 2012. "From Dividual and Individual Selves to Porous Subjects." The Australian Journal of Anthropology 23 (1): 50-64. 
Strathern, Marilyn. 1988. The Gender of the Gift: Problems with Women and Problems with Society in Melanesia. Berkeley, California: University of California Press.

Thangarajah, C.Y. 2003. "Veiled Constructions: Conflict, Migration and Modernity in Eastern Sri Lanka." Contributions to Indian Sociology 37 (1-2): 141-62.

The Lede. 2019. "Unemployment In Kerala Double The National Average." The Lede, February 12, 2019. https://www.thelede.in/ kerala/2019/02/12/unemployment-data-kerala.

Thiranagama, Sharika. 2019. "Rural Civilities: Caste, Gender and Public Life in Kerala." South Asia:Journal of South Asian Studies 42 (2): 310-27.

Zachariah, K. C., Elangikal Thomas Mathew, and S. Irudaya Rajan. 2003. Dynamics of Migration in Kerala: Dimensions, Differentials, and Consequences. New Delhi: Orient Longman.

\section{(c) $1 \oplus \Theta$}

This work is licensed under a Creative Commons

Attribution-NonCommercialNoDerivatives

4.0 International License. 